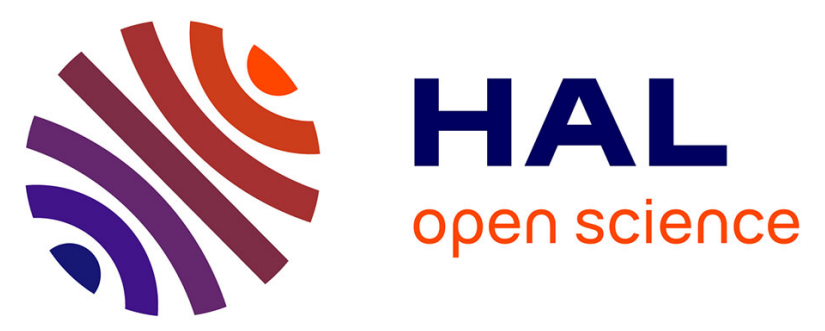

\title{
Effect of fire regimes on the demographic parameters of the perennial tussock grasses of a humid savanna
}

Kouamé Koffi, Aya Brigitte N'Dri, Jean-Christophe Lata, Souleymane Konaté, Tharaniya Srikanthasamy, Sarah Konaré, Marcel Konan, Sébastien Barot

\section{- To cite this version:}

Kouamé Koffi, Aya Brigitte N'Dri, Jean-Christophe Lata, Souleymane Konaté, Tharaniya Srikanthasamy, et al.. Effect of fire regimes on the demographic parameters of the perennial tussock grasses of a humid savanna. Journal of Vegetation Science, 2019, 30 (5), pp.950-962. 10.1111/jvs.12788 . hal-02307492

\section{HAL Id: hal-02307492 https: / hal.sorbonne-universite.fr/hal-02307492}

Submitted on 7 Oct 2019

HAL is a multi-disciplinary open access archive for the deposit and dissemination of scientific research documents, whether they are published or not. The documents may come from teaching and research institutions in France or abroad, or from public or private research centers.
L'archive ouverte pluridisciplinaire HAL, est destinée au dépôt et à la diffusion de documents scientifiques de niveau recherche, publiés ou non, émanant des établissements d'enseignement et de recherche français ou étrangers, des laboratoires publics ou privés. 
DR. KOUAMÉ FULGENCE KOFFI (Orcid ID : 0000-0002-5275-2146)

Article type : Research Article

Handling Co-ordinating Editor: John Morgan

Title: Effect of fire regimes on the demographic parameters of the perennial tussock grasses of a humid savanna

Running title: Fire effect on grass demography

Kouamé Fulgence Koffi ${ }^{1,2}$, Aya Brigitte $\mathrm{N}^{\prime}{ }^{2}{ }^{1}$, Jean-Christophe Lata ${ }^{2,3}$, Souleymane Konate $^{1}$, Tharaniya Srikanthasamy ${ }^{2}$, Sarah Konaré$^{2}$, Marcel Konan ${ }^{1}$, Sébastien Barot $^{2}$

${ }^{1}$ Université Nangui Abrogoua, UFR des Sciences de la Nature, Laboratoire d'Ecologie et Développement Durable (LEDD), Station d'Ecologie de Lamto/CRE, 02 BP 801 Abidjan 02, Côte d'Ivoire

${ }^{2}$ Sorbonne Université, UMR 7618 IEES-Paris (IRD, CNRS, Université Paris Diderot, UPEC, INRA), 4 Place Jussieu, 75005 Paris, France

3 Department of Geoecology and Geochemistry, Institute of Natural Resources, Tomsk Polytechnic University, 30, Lenin Street, Tomsk 634050, Russia

This article has been accepted for publication and undergone full peer review but has not been through the copyediting, typesetting, pagination and proofreading process, which may lead to differences between this version and the Version of Record. Please cite this article as doi: $10.1111 /$ jvs. 12788

This article is protected by copyright. All rights reserved. 
Correspondence: E-mail: fulkoffi@yahoo.fr Tel: +33144274730 / +22557856735

Funding: This publication was made possible thanks to the $\mathrm{PhD}$ grant provided by the Direction of Research and Training in the South of the Institute of Research for Development (IRD-DPF) to K. F. Koffi

Conflict of Interest Statement: This work has not been published previously, and it is not under consideration for publication elsewhere. All authors approve its publication in your journal and no conflict of interest was noted.

\footnotetext{
ABSTRACT

Questions: Perennial tussock grasses represent the principal fuel source for savanna fires, however basic information about the impact of fire on their demography remains scarce. Do dominant perennial grass species differ in their demographic parameters? What is the overall impact of tussock circumference and fire regimes on grass demographic parameters? Do grass species differ in the sensitivity of their demographic parameters to fire regimes and tussock circumference?
}

Location: The study site is located in the savanna of the Lamto reserve, in the center of Ivory Coast $\left(6^{\circ} 9\right.$ to $6^{\circ} 18 \mathrm{~N} ; 5^{\circ} 15$ to $\left.4^{\circ} 57 \mathrm{E}\right)$.

Methods: Data on the nine dominant species of tussock grasses were sampled over one year under four fire treatments (early fire, mid-season fire, late fire and no fire). We studied the impact of these fire treatments and tussock circumference on five demographic parameters: mortality, fragmentation (the division of a tussock into several smaller ones), growth, retrogression (the decrease in tussock size) and fecundity.

This article is protected by copyright. All rights reserved. 
Results: All demographic parameters varied among species and across the fire regimes. The late fire had the largest negative effect on all parameters except fecundity. Schizachyrium platyphyllum was the most disadvantaged species by fire in terms of mortality, retrogression and growth, whilst Andropogon ascinodis was the most prone to fragmentation. Hyparrhenia smithiana and Sorghastrum bipennatum produced the most seeds and Brachiaria brachylopha produced the most new tussocks. The circumference of perennial grasses impacted all demographic parameters. Small individuals had the highest mortality and growth rates, while large individuals showed the highest fragmentation and retrogression rates, and produced the most seeds.

Conclusions: This study showed that perennial grass species differed in their sensitivity to fire treatments. Nevertheless, the mid-season fire could be advised to managers for the sustainable management of the Lamto savanna.

Key words: demographic parameter, fecundity, fire regime, humid savanna, Lamto, mortality, perennial tussock grass, tussock circumference, tussock fragmentation, tussock retrogression.

\section{INTRODUCTION}

Fires are critical to the functioning of savannas (Abbadie, Gignoux, Lepage, \& Roux, 2006; Bond, Woodward, \& Midgley, 2005). In particular, fires are used to conserve and sustainably manage savannas by stopping tree encroachment (Case \& Staver, 2017; Stevens, Lehmann, Murphy, \& Durigan, 2017), which is a common phenomenon occurring world-wide in savannas (Archer, Schimel, \& Holland, 1995; Moleele, Ringrose, Matheson, \& Vanderpost, 2002) and could lead to the disappearance of these ecosystems (Gillson, 2015). In this perspective, different fire regimes are studied to compare their impact on savanna functioning 
to find the most appropriate regime (Case \& Staver, 2017; Stevens et al., 2017). These studies mostly focus on trees (February, Higgins, Bond, \& Swemmer, 2013; Gignoux, Lahoreau, Julliard, \& Barot, 2009; Smit, Asner, Govender, Vaughn, \& van Wilgen, 2016) with few studies focusing on fire impacts on perennial grasses for which basic demographic information is scarce, especially in West Africa (Keeley, Pausas, Rundel, Bond, \& Bradstock, 2011; O’Connor, 1994).

Perennial tussock grasses generally dominate the herbaceous layer of humid savannas that is the main source of fire fuel (Williams, Müller, Wahren, Setterfield, \& Cusack, 2003). These grasses are adapted to fires. Indeed, their aboveground biomass burns while belowground biomass tends to stay alive (Monnier, 1968; Sarmiento, 1992), which allows the quick regrowth of tussocks after fire (Abbadie et al., 2006; Moore, Camac, \& Morgan, 2019; Sarmiento, 1992). Nevertheless, fires and fire regimes likely impact the demographic parameters of grass tussocks: mortality (Zimmermann, Higgins, Grimm, Hoffmann, \& Linstädter, 2010), retrogression i.e. decrease in tussock size (Canales, Trevisan, Silva, \& Caswell, 1994), growth i.e. increase in tussock size (Yuan, Liang, \& Zhang, 2016), fragmentation i.e. the division of a tussock into several smaller tussocks which leads to a form of clonal reproduction (Fair, Lauenroth, \& Coffin, 1999; Hartnett \& Bazzaz, 1985), and fecundity (Brys, Jacquemyn, \& De Blust, 2005). Our first goal is to document for perennial grasses the impact of contrasted fire regimes and the absence of fire on these demographic parameters. These parameters are hypothesized to vary with grass species, fire regimes and the interaction between the two, if species have different sensitivities to fire regimes. Testing this broad hypothesis is an important step to choose the best fire regime for the sustainable management of savannas.

This article is protected by copyright. All rights reserved. 
The demographic parameters of tussock grasses also likely depend on tussock circumference, since plant demographic parameters are highly dependent on plant size (Caswell, 1989) and tussock circumference is considered as a good proxy of their size (Garnier \& Dajoz, 2001; Lata, 1999). We therefore studied the impact of tussock circumference on the five demographic parameters (see above) and tested interactions between the circumference, fire regimes and species, because tussock circumference might have different demographic impacts in different species and under different fire regimes.

In West African humid savannas, three fire regimes are generally described (Bruzon, 1994; N'Dri et al., 2018): (1) Early fires occur at the beginning of the dry season when vegetation is not fully dry, (2) Mid-season fires occur in the middle of the dry season when grass biomass is dry and neither grasses nor trees are growing, (3) Late fires occur at the end of the dry season when trees and grasses have resumed their growth. We analyzed over one year the impact of these three fire regimes and the absence of fire on five demographic parameters (see above) of the nine dominant perennial grass species of the Lamto savanna (Abbadie, Gignoux, Le Roux, \& Lepage, 2006) in Ivory Coast. This savanna is a natural reserve and has been managed since 1962 using the mid-season fire. This fire regime negatively impacts the demography of trees in this savanna (Gignoux, Dajoz, Durand, Garnier, \& Veuille, 2006; Gignoux et al., 2009) and is critical to maintain a savanna ecosystem, i.e. to maintain areas deprived of trees. In turn, this is important to preserve the whole biodiversity of Lamto savanna, which includes forbs growing in the herbaceous layer, and a range of animals (insects, small mammals and larger mammals such as the kob antelope) that all depend on the presence of a grass layer (Mishra \& Young, 2014; Ritchie, Tilman, \& Knops, 1998). For almost thirty years, some bush encroachment has nevertheless been observed in Lamto savanna, with areas transformed into savanna woodland (Dauget \& Menaut, 1992; Gautier, 1990). This justifies testing the impact of the different possible fire regimes on the tree 
community of Lamto savanna but it is also important to test whether these fire regimes are not detrimental to the whole grass layer, or to some grass species, therefore threatening grass diversity. We specifically addressed the following questions: (1) How does tussock circumference affect grass demographic parameters? (2) What is the overall impact of fire regimes on grass demographic parameters? (3) Do grass species differ in the sensitivity of their demographic parameters to fire regimes and tussock circumference? (4) What is the fire regime that better maintains grass diversity and abundances?

\section{MATERIAL AND METHODS}

\section{Study site description}

The study site is located in the savanna of the Lamto reserve (Abbadie et al., 2006), in the center of Ivory Coast $\left(6^{\circ} 9\right.$ to $6^{\circ} 18 \mathrm{~N} ; 5^{\circ} 15$ to $\left.4^{\circ} 57 \mathrm{E}\right)$ where the vegetation is a forestsavanna mosaic, with a tropical humid climate. The average annual rainfall is $1200 \mathrm{~mm}$ and the mean annual temperature is $27^{\circ} \mathrm{C}$. Mid-season fire has been used for the management of the reserve since 1962. The grass stratum is mostly composed of nine perennial grass species: Andropogon ascinodis C. B. Cl., Andropogon canaliculatus (Schumach.), Andropogon schirensis (Hochst. ex A. Rich), Brachiaria brachylopha Stapf (now Urochloa serrata, Soreng et al., 2015; Sosef, 2016), Hyparrhenia diplandra (Hack.) Stapf, Hyparrhenia smithiana (Hook. f.) Stapf, Loudetia simplex (Nees) C.E. Hubbard, Sorghastrum bipennatum (Hack.) Pilg. and Schizachyrium platyphyllum (Franch.) Stapf (Menaut \& Abbadie, 2006).

\section{Study plots}

Three separate blocks of 3.72 ha each were identified in the shrubby savanna zone. In each block, four plots were established in September 2013 to implement four fire treatments (N'Dri et al., 2018): early fire (in November), mid-season fire (in January), late fire (in March) and no fire (unburned plot). In each of these plots, a plot was delimited to monitor 
grass demography. This results in a total of 12 plots ( 3 blocks $\times 4$ plots) on which data were collected. These plots were $5 \times 5-\mathrm{m}$ for early fire, late fire and no fire treatments, and $5 \times 10$ $\mathrm{m}$ for the mid-season fire.

\section{Data collection}

The first sampling of perennial grasses took place in April and May of 2015 after 2 yrs of implementation of the different fire regimes. All tussocks with more than five tillers were labelled with a fire-proof metal label tied to a metal peg. Pegs were placed at the base of each tussock in the same direction to avoid confusing neighboring tussocks, skipping a tussock or repeatedly counting the same tussock. Grass species were identified using the herbarium of the Ecology Station of the Lamto Reserve. The circumference of each tussock was measured at the soil surface using a measuring tape.

In May and June 2016, all labelled tussocks were retrieved to determine their status, i.e. dead or alive. When a tussock was alive, it was determined whether it was fragmented or not, i.e. whether the tussock was divided in at least two independent tussocks because of the death of groups of tillers. In cases of fragmentation, the number of fragment was recorded, the old peg was given to the principal fragment (i.e. the fragment with the largest circumference) and the other fragments were each labelled with a new peg. New tussocks arising from seed germination were also labeled. These new tussocks were distinguished from fragments of old tussocks due to their very small sizes and the absence of mark of fire at the base of the tussocks (remains of burnt stems). The circumference $(\mathrm{cm})$ of all live tussocks (old live tussocks, tussock fragments and new tussocks) was measured. The difference between the new circumference (in 2016) and the former one (in 2015) was calculated to determine tussocks that had grown (difference $>5 \mathrm{~cm}$ ), tussocks that had retrogressed (difference $<-5$ $\mathrm{cm})$ and tussock that had not change in size $(-5 \mathrm{~cm}<$ difference $<5 \mathrm{~cm})$. The $5 \mathrm{~cm}$ threshold was chosen due to the uncertainty in the precise circumference measurement. Finally, fifteen 
tussocks of various circumferences were chosen for each species on each plot to count the number of seeds produced from mid-November to mid-March 2016 before each fire regime (depending on the maturation of seeds for each species and plot). The number of new tussocks (deriving from seed germination, as proved by the absence of marks of fire) and the number of seeds produced per tussock were used to estimate fecundity. The fecundity in new tussocks was calculated as the number of new tussocks per adult of the same species in a plot, assuming that all individuals have the same fecundity regardless of their circumference.

\section{Data analyses}

All statistical analyses were performed using the 3.1.1 version of the $\mathrm{R}$ software. Mixed linear models with the block as random effect were used to account for the dependence of measurements within the same block for variables measured at the tussock scale, i.e. for all variables except the fecundity (measured as a number of seeds). The glmer procedure of the Ime4 package was used to test the effects of fire treatments, species, circumference and all interactions between them on tussock probability to die, to become fragmented, to grow (increase in circumference $>5 \mathrm{~cm}$ ) and to retrogress (decrease in circumference $>5 \mathrm{~cm}$ ), using a binary logistic regression model. Linear models using $1 \mathrm{~m}$ procedure were used to analyse: (1) the effect of fire treatments and species on the average fecundity measured as the number of new tussocks per adult; (2) the effect of fire treatments, grass species and tussock circumference on the number of seeds produced by tussock (in this case no random effect was used because there was no significant block). The Tukey Honest Significant Difference (HSD) post-hoc test was used to compare the different modalities of factors (fire treatments and species) with a significant effect, using the glht procedure of the multcomp package. The cld procedure was used following Tukey HSD post-hoc tests to group non-significantly different modalities. All tests were achieved with a significance level $\alpha=0.05$.

This article is protected by copyright. All rights reserved. 


\section{RESULTS}

During the first sampling year (i.e. 2015) 5116 tussocks were found on all plots. During the second year (i.e. June 2016) a total of 5355 tussocks were recorded with 797 new tussocks (Table 1). One hundred and ninety tussocks (4\% of the tussocks) had become fragmented and 558 tussocks (11\% of the tussocks) had died. Fifty percent of the new tussocks were fragments coming from old tussocks, $43 \%$ had arisen from seed germination and $6 \%$ were small tussocks that had not been tagged the first year. About $34 \%$ of alive tussocks had not changed in size (decrease or increase in circumference $>5 \mathrm{~cm}$ ), $43 \%$ had grown (increase in circumference $>5 \mathrm{~cm}$ ) and $23 \%$ had retrogressed (decrease in circumference $>5 \mathrm{~cm}$ ).

\section{Mortality}

Grass mortality decreased with increased tussock circumference (Table 2, circumference effect) from about $30 \%$ for the smallest circumferences $(3-10 \mathrm{~cm}$ circumference) to $0 \%$ for the highest circumferences (about $150 \mathrm{~cm}$ ) irrespective of fire treatment (Figure 1c) and grass species (Figure 1d). Overall, mortality differed significantly between fire treatments and species (Table 2, Fire treatment $\mathrm{x}$ Species). This mortality was significantly higher in the late fire treatment compared to other fire treatments. Mortality was significantly lower for the early and mid-season fire treatments than for the no fire treatment (Tukey HSD test, $p<0.01$. Figure 1a). Mortality of S. platiphylum was significantly higher than that of any of the other species (Tukey HSD test, $p<0.001$. Figure 1b). Andropogon schirensis, $H$. diplandra and $H$. smithiana had higher mortality than L. simplex (Tukey HSD test, $p<0.001, p=0.016$ and $p=$ 0.018 respectively. Figure $1 \mathrm{~b})$ and $A$. canaliculatus had lower mortality than A. schirensis (Tukey HSD test, $p=0.002$. Figure $1 b$ ).

The significant effect of the "Fire treatment x Species" interaction on mortality (Table 2) revealed by the glmer suggests that species differed in their sensitivity to fire treatment. The impact of circumference differed between fire treatments (Table 2, significant interaction 
between fire treatment and circumference. Figure 1c) and species (Table 2, significant interaction between species and circumference. Figure 1d). Tussock mortality decreased slower with circumference for the late fire and the no fire treatments than for the early and mid-season fire treatments (Tukey HSD test, $p<0.01$ ). Tussock of $S$. platiphylum revealed more rapid mortality when compared to the tussocks of $A$. canaliculatus, $H$. diplandra and $H$. smithiana (Tukey HSD test, $p=0.048 ; p<0.001$ and $p=0.005$ ). The mortality decreased slower with circumference for $A$. schirensis than for $H$. diplandra (Tukey HSD test, $p=$ $0.032)$.

\section{Tussock fragmentation}

Overall, the probability of fragmentation increased with tussock circumference from 0.2 for the smallest circumferences to about 0.8 for the highest circumferences (Table 2, circumference effect) regardless of fire treatment (Figure 2c) and species (Figure 2d). This probability varied with the fire treatment (Table 2, fire treatment effect) and the grass species (Table 2, species effect) and was significantly higher for the late fire (Tukey HSD test, $p<$ 0.01. Figure 2a). The probability was higher for A. ascinodis than for A. schirensis, $H$. diplandra and L. simplex (Tukey HSD test, $p=0.032, p=0.014$ and $p=0.001$ respectively). Andropogon canaliculatus had a higher probability of fragmentation than $H$. diplandra and $L$. simplex (Tukey HSD test, $p=0.046$ and $p=0.005$ respectively. Figure $2 b$ ).

\section{Tussock growth}

The probability of tussock growth decreased with tussock circumference (Table 2, circumference effect) from approximately 0.6 for the smallest circumferences to about 0.2 for the highest circumferences (logistic regression, $p<0.05$ ) for all fire treatments (Figure $3 \mathrm{c}$ ) and all species (Figure 3d). Generally, regardless of the circumference, this probability differed significantly between fire treatments and species. It was higher for the mid-season than for the late fire (Tukey HSD test, $p<0.001$. Figure 3a). Schizachyrium platiphylum had 
a lower growth probability than all other species (Tukey HSD test, $p<0.01$ ) but $B$. brachylopha that had a lower growth probability than $H$. diplandra (Tukey HSD test, $p=$ 0.02. Figure $3 b)$.

The "Fire treatment $\mathrm{x}$ Species" interaction had a significant effect on the growth probability (Table 2) showing that species differed in the sensitivity of their growth to the fire treatment. The impact of circumference differed between fire treatments (Table 2, significant interaction between fire treatment and circumference, Figure 3c) and species (Table 2, significant interaction between species and circumference, Figure 3d). Tussock probability to grow decreased quicker with circumference for the late fire than for the early fire treatment (Tukey HSD test, $p=0.022$ ). This probability decreased with circumference slower for the early fire and no fire treatments than for the mid-season fire (Tukey HSD test, $p<0.001$ ). Tussock growth probability decreased with circumference slower for $S$. platiphylum than for $H$. diplandra, H. smithiana, L. simplex and S. bipennatum (Tukey HSD test, $p<0.01$ ) and slower for A. ascinodis and A. canaliculatus than for $H$. smithiana (Tukey HSD test, $p=$ 0.032 and $p=0.031$ respectively).

\section{Tussock retrogression}

The probability of tussock retrogression increased with tussock circumference (Table 2, circumference effect) from about 0.1 for the smallest circumference to about 0.9 for highest circumference (logistic regression, $p<0.01$ ) whatever the fire treatment (Figure 4c) and whatever the species (Figure 4d). Overall, this probability differed significantly between fire treatments and species. It was significantly higher for the late fire than for the other fire treatments (Tukey HSD test, $p<0.001$. Figure $4 a$ ) and was higher for the no fire treatment than for the mid-season fire (Tukey HSD test, $p=0.001$ ). The overall probability of retrogression was significantly higher for S. platiphylum than for A. canaliculatus, A. 
schirensis, H. diplandra and L. simplex (Tukey HSD test, $p<0.01$ ). H. smithiana presented a higher probability of retrogression than A. canaliculatus and H. diplandra (Tukey HSD test, $p$ $=0.02$, Figure $4 \mathrm{~b})$.

The "Fire treatment $\mathrm{x}$ Species" interaction had a significant effect on the retrogression probability (Table 2). The impact of circumference differed between fire treatments (Table 2, significant interaction between fire treatment and circumference, Figure 4c) and species (Table 2, significant interaction between species and circumference, Figure 4d). Tussock probability of retrogression increased slower with circumference for the mid-season fire than for all other fire treatments (Tukey HSD test, $p<0.01$ ). It increased quicker for $S$. platiphylum and A. canaliculatus than for L. simplex (Tukey HSD test, $p=0.013$ and $p=$ 0.042 respectively).

\section{Fecundity}

The interaction between fire treatment, species and circumference significantly affected the number of seeds produced by grass tussocks (Table 2). Overall, whatever the fire treatment (Figure 5c) and the species (Figure 5d) the number of seeds significantly increased with tussock circumference (Figure 5d). More seeds were produced by tussock on the no fire plots than on the early and mid-season fire plots (significant fire treatment effect, Table 2 and Tukey HSD test, $p=0.002$ and $p<0.001$ respectively, Figure 5a). Hyparrhenia smithiana and S. bipennatum produced more seeds than the other species (significant effect of species, Table 2 and Tukey HSD test, $p<0.001$, Figure 5b). The "species $\mathrm{x}$ fire treatment" interaction was significant (Table 2): S. bipennatum had more seeds in the no fire treatment than in the other fire treatments (Tukey HSD test, $p<0.001$ ). Brachiaria brachylopha did not produce any seed on the early and late fire plots. Loudetia simplex produced more seeds on the midseason fire plots but none on the no fire plots. Schizachyrium platiphylum did not produce any seed on the early and mid-season fire plots. The number of seeds increased quicker with 
circumference for the no fire treatment than for the other fire treatments (significant interaction between circumference and fire treatment, Table 2, Tukey HSD test, $p<0.01$. Figure 5c). The number of seeds increased quicker with circumference for H. smithiana and S. bipennatum than for the other species (significant interaction between circumference and species, Table 2, Tukey HSD test, $p<0.01$. Figure 5d).

The production of new tussocks per adult tussock varied with the species (Table $2, \mathrm{~F}_{8.51}=$ 4.38; $p=0.0004)$. Brachiaria brachylopha produced more new tussocks than all the other species (Tukey HSD test, $p<0.05$. Figure 6) except $S$. bipennatum (Tukey HSD test, $p=$ 0.25). The fire treatment and the interaction between fire and species had no effect on grass new tussock production (Table $2, \mathrm{~F}_{24.51}=1.66 ; p=0.06$ ).

\section{DISCUSSION}

\section{Tussock mortality}

Although tussock mortality was low $(11 \%)$ in our study compared to values obtained in Namibia (57\%) by Zimmermann et al. (2010) or in Argentina (55 - 85\%) by Pelaez, Boo, Mayor, \& Elia (2001), it remained very high compared to that obtained by Gignoux et al. (2006) in the Lamto savanna. Grass mortality decreased with tussock circumference irrespective of the fire treatment and the species showing that small individuals are more likely to die than larger ones, as reported by other studies that considered basal diameter as a measure of size for grass tussocks (Garnier \& Dajoz, 2001; O’Connor, 1994; Silva, Raventos, \& Caswell, 1990). Overall, this confirms that the size of plant individuals allows predicting their fate (Silva \& Castro, 1989). The causes of the death of tussocks are not precisely identified but, most probably, small tussocks are more vulnerable to accidents (e.g. trampling by buffalos in Lamto savanna) and to the exhaustion of resources due to repeated fires burning aboveground biomass and to the competition with larger tussocks. Indeed, small 
tussocks have fewer tillers, lower root biomass, and can therefore store less photosynthates in their roots during the dry season (Gignoux et al., 2006).

The late fire and the no fire treatments caused higher mortality than the mid-season and early fire treatments. This can be explained by the fact that late fire occurs at the beginning of the wet season, when grasses are vulnerable because they have already resumed their annual development cycle. The underground living buds ensuring their survival have already started their development, making them more vulnerable to fire. In turn, this probably makes small tussocks more vulnerable to late fire because they have fewer meristems: these tussocks cannot regrow if all their meristems have been killed and thus die. Silva et al. (1990) obtained similar results with two perennial grass species on a plot burned at the end of the dry season. The effect of the no fire treatment could be explained by the accumulation of dead aboveground biomass (Zimmermann et al., 2010) that could be detrimental to the resumption of tussock growth at the beginning of the rainy season. Moreover, the absence of fire could exacerbate competition between tussocks and increase the success of larger tussocks (Milton \& Dean, 2000). Fire allows the access to light to all tussocks, regardless of their size, at least at the beginning of the dry season, when there is a low aboveground biomass. Conversely, the absence of fire could directly kill small tussocks that have not stored enough photosynthates to grow through the accumulating aboveground dead biomass.

The difference of mortality observed between species confirms that species differ by the effect of tussock size on demographic parameters. The studied grass species can be sorted in three distinct groups according to their tussock circumference i.e. large, medium and small size species (Koffi et al., 2019). In this context, the high mortality of S. platiphylum can be explained by the fact that the species is mostly represented by small tussocks.

This article is protected by copyright. All rights reserved. 


\section{Tussock fragmentation}

As found by César (1992) and Gignoux et al. (2006), we demonstrated the existence of tussock fragmentation in Lamto grasses. Such fragmentation has already been observed for tussock grass species (Festuca gracillima) in South America (Oliva, Collantes, \& Humano, 2005), in North American prairies (Schizachyrium scoparium, Butler \& Briske (1988)), in Australia (Astrebla spp. - Orr, 1980) and for several other perennial grass species in South Africa (Hartnett \& Bazzaz, 1985; O’Connor, 1994).

Fragmentation probability increased with tussock circumference. This is consistent with César (1992) and Oliva et al. (2005) who found that larger grass tussocks produced new individuals by fragmentation. The process of tussock fragmentation has never been thoroughly analyzed. Nevertheless, it is clearly due to the death of the tillers in some parts of the tussock. The probability of fragmentation could increase with tussock circumference for at least three reasons. (1) Large tussocks produce more biomass and thus more fuel for fires, which could locally increase fire intensity (Lata, 1999). However, the probability of fragmentation also increased with tussock size in the no fire treatment. (2) This suggests that the death of tillers could also be due to a higher competition for water, mineral nutrients and light between tillers in larger tussocks. Tillers from the center of the tussocks would lose this competition because they have less access to light and, maybe, water and mineral nutrients than external tillers. (3) Finally, since tussocks are growing by the production of new tillers at their periphery (Lata, 1999), tillers from the tussock centers are likely to be older and could be senescent, which would increase their mortality.

The probability of tussock fragmentation was higher for the late fire, probably due to the same mechanism that increases mortality in this fire treatment: late fire is more likely to kill tillers that are resuming their growth at the beginning of the rainy season, when only a fraction of tillers dies, fragmentation may occur.

This article is protected by copyright. All rights reserved. 
Andropogon canaliculatus and A. ascinodis had higher probabilities of fragmentation than $A$. schirensis, H. diplandra and L. simplex, but there was no interaction with fire treatment or tussock circumference. Andropogon canaliculatus was the species that formed the largest tussocks while A. ascinodis possessed medium size tussocks. These two species were opposed to A. schirensis and L. simplex that had small tussocks and H. diplandra that formed large tussocks (Koffi et al., 2019) but with fewer large tillers (personal observation). This supports the assumption that tussock fragmentation is influenced by the size and the number of tillers by tussock.

\section{Tussock growth and retrogression}

The tussock probability to grow was significantly lower for the late fire regime. This could be explained by the severity of this fire regime (Louppe, Oattara, \& Coulibaly, 1995). Such fire regime could prevent tussock growth by killing some tillers. Some authors showed, on the contrary, that the growth of perennial grass tussocks was higher in the case of intensive disturbance (O'Connor, 1994; Yuan et al., 2016). According to them, the late fire should rather stimulate tussock growth by reducing aboveground biomass, subsequently reducing competition and increasing light availability (Zimmermann et al., 2010). The stronger negative impact of the late fire, that does not have a higher intensity than the other fire regimes in Lamto savanna (N'Dri et al., 2018), is likely explained by the fact that grass tussocks have resumed their growth at the moment of late fire, so that late fire as a stronger negative impact on growth (and other demographic parameters, see above).

Tussock probability to grow decreased with circumference whatever the fire treatment and the species. Indeed, the larger a tussock is, the less resource (water, mineral nutrients, light) becomes available because the local tiller density increases, which likely increases competition between tillers and decreases the capacity to grow new tillers. In comparison to the mid-season fire, the absence of fire can also be detrimental to tussock growth as shown by 
Garnier and Dajoz (2001) or Loydi, Eckstein, Otte \& Donath (2013). For these authors, the accumulation of unburned litter could reduce the growth of seedlings that have lower access to light.

There were small differences between species in their probability to grow. For example, $S$. platiphylum had overall a lower probability to grow that is only weakly sensitive to tussock size. On the contrary, A. ascinodis had a higher overall probability to grow than other species and this probability was high whatever the tussock size. This is consistent with the observed differences in tussock size between species (Koffi et al., 2019). Schizachyrium platiphylum generally formed small tussocks with few thin and short tillers (personal observation). Due to competition with taller tussocks, this could prevent $S$. platiphylum tussocks from absorbing enough light and from producing new tillers to enlarge their tussocks. On the contrary, $A$. ascinodis had many tall tillers (personal observation), which could facilitate the accumulation of resources that can be used to grow more tillers and enlarge its tussocks (Fetcher \& Shaver, 1982).

The probability of tussocks retrogression increased with tussock circumference. Retrogression is due to the death of tillers, especially at the periphery of tussocks (Canales et al., 1994). Our result would again be due to a decrease in resource availability with tussock size, or maybe to a local increase in fire intensity with tussock biomass, as for fragmentation. The retrogression of tussocks was significantly more likely for the late fire than for the other fire regimes, certainly due to the same mechanism explaining the lower growth and higher mortality of tussocks for this fire regime.

The probability of retrogression was significantly higher for S. platiphylum than for $A$. canaliculatus, A. schirensis, H. diplandra and L. simplex, and H. smithiana presented a higher probability of retrogression than A. canaliculatus and $H$. diplandra. This is consistent with the fact that $S$. platiphylum and $H$. smithiana had on the average small tussocks (Koffi et 
al., 2019): higher rates of retrogression tend to lead to small tussocks. As for the effect of tussock size on growth, this could be explained by the lower capacity of resource accumulation of the smaller tussocks.

\section{Fecundity}

The number of seeds per tussock significantly increased with tussock circumference. Garnier \& Dajoz (2001) obtained similar results with $H$. diplandra in both burned and unburned plots of the Lamto savanna. This confirms that for plants, size strongly influences fecundity (Watkinson \& White, 1986; Weaver \& Cavers, 1980) and suggests that this relation between plant size and plant fecundity is linear (Rees \& Crawley, 1989). This is due to the fact that larger tussocks have more tillers, can produce more biomass and, everything else being equal, more seeds.

More seeds per tussock were produced in the no fire than in the early and mid-season fire treatments. This could be due to the return of more dead biomass and mineral nutrients to the soil in the absence of fire, because fires lead to the loss of the aboveground biomass and an important fraction of the mineral nutrients it contains (N'Dri, Kone, Loukou, Barot, \& Gignoux, 2018). This is in agreement with Crowley \& Garnett (1999). However, Brys et al. (2005) found that seed production was two times higher and seedling density six time higher in burned than in unburned savanna plots. Several other grass species have also been shown to produce more seeds in burned plots (Canales et al., 1994; Garnier \& Dajoz, 2001). The reason for these contrasting results remains unclear. The absence of difference between the no fire and late fire treatments could be explained by the fact that, tussocks have the same time to produce and mature seeds in these treatments. While tillers stop growing during the dry season, some leaves remain green during at least a part of this season, which likely favors seed feeling and maturation till the death of aboveground biomass at the end of the dry season or due to fire, i.e. in March in the late and no fire treatments. Moreover, the number of seeds 
increased quicker with circumference for the no fire treatment than for the other fire treatments. This is likely due to the increased competition for light in the no fire treatment and the fact that this treatment favors large tussocks.

Hyparrhenia smithiana and S. bipennatum produced more seeds per tussock than the other species and their number of seeds increased quicker with circumference. As seen above, these two species are among the ones with the lowest probability of fragmentation and the smallest tussocks (Koffi et al., 2019). This suggests that small size species reproduce less by fragmentation but more by seeds likely explaining why these two species invest more in seed production relatively to their size. In particular, seed production might decrease in a fire treatment because it requires a particular timing from flower development to seed filling and because this timing is disturbed by fire (Brys et al., 2005; Silva \& Ataroff, 1985). This could be for example the case for $B$. brachylopha in the early and late fire treatments, and $S$. platyphyllum in the early and mid-season fire.

The production of new tussocks by seed germination varied with the species but not with the fire treatment. Such effects should depend on differences in seed production, seed germination or seedling survival and growth (Brys et al., 2005). In our case, B. brachylopha produced more tussocks and fewer seeds than $H$. smithiana and $S$. bipennatum. This suggests that $B$. brachylopha has a higher germination rate or higher seedling survival rate than $H$. smithiana and $S$. bipennatum. In turn, this suggests that the seeds and seedling of $B$. brachylopha are more adapted to fire than $H$. smithiana and S. bipennatum. Testing further these hypotheses would require monitoring seed germination and the dynamics of young seedlings in the different fire treatments.

This article is protected by copyright. All rights reserved. 


\section{Conclusion}

In the humid savanna of Lamto, the grass species differ by their demographic parameters and the sensitivity of their demographic parameters to both fire regimes and tussock circumference. Overall our results confirm that the most benign fire treatment for grasses is the mid-season fire treatment. This treatment, which has been applied for more than 50 years in Lamto savanna, is likely to maintain the highest diversity of perennial grasses because it is not particularly detrimental to any of their dominant species. Outside the Lamto reserve, due to farmer activities, the fire often burns savannas before the period of the mid-season fire (i.e. mid-January). Because of an absence of fire-break around the Lamto reserve, these fires often also burn the reserve savanna, disturbing the prescribed mid-season fire regime. However, our results show that such perturbations and the early-fire regime are not too detrimental to the demography of perennial grasses. On the contrary, the late fire regime would likely decrease the abundances of all perennial grass species and should be avoided to maintain the integrity of the grass community. Nevertheless, the late fire is likely the fire regime that has also the stronger negative impact on tree demography because, as for grasses, tree saplings and seedlings resume their growth at the beginning of the rainy season and are likely more vulnerable to fire (Laris, Koné, Dadashi, \& Dembele, 2017). This would suggest that maintaining at the same time savanna structure (the tree grass equilibrium) and the grass community would require alternating mid-season and late fires.

New results are required to test the long term impact of fire regimes on grass biomass and the abundance and diversity of forbs (Abella \& Fornwalt, 2015). To predict the long term consequences of the fire regimes on the relative abundance of the different grass species, it is necessary to integrate all demographic parameters within the same framework. This will be achieved using our data to parameterize matrix population models (Caswell, 1989). Such models could predict the effect of the date and frequency of fires on the grass community. 
Finally, the mechanisms explaining the differences between species are so far largely unknown. They could be determined by further analyzing the grass species traits: the use of mineral nutrient, water and photosynthesis efficiency, phenology, classical root and leaf traits (Violle et al., 2007).

\section{ACKNOWLEDGMENTS}

This publication was made possible thanks to the $\mathrm{PhD}$ grant provided by the Direction of Research and Training in the South of the Institute of Research for Development (IRD-DPF). This study was conducted within the project "Integrated and Sustainable Management of Savannah Ecosystems" financed by IRD within the "Young Associated Team" program (JEAI-GIDES) and was helped by the French national program EC2CO MicrobiEn 2014 (project: Impact de la diversité des Graminées et ligneux de savane sur la diversité microbienne et le fonctionnement des sols) and the Sorbonne Université programme Emergence 2016 (project: SU-16-R-EMR-37-WASCINNI). We thank Yéo Kolo, the Director of the Ecology Station of Lamto, where this study had taken place. We thank all students (particularly Drissa Soro, Prospère Kpangba, Louis N'Guessan, Evelyne Kouakou, Sylvain Yoboué and Jean-Noël Kpré) who helped during data collection.

Author contributions (optional): All authors have been involved in the design of the experiments. KF Koffi, AB N'Dri, JC Lata, M Konan and S Barot have achieved the field work. KF Koffi, S Konaré and S Barot have achieved the statistical analyses. KF Koffi, S Barot, S Konaté, AB N'Dri and JC Lata have written the article.

Data Availability Statement: Our raw data are now available to the scientific community on the Mendeley repository website at: http://dx.doi.org/10.17632/jvx4f5gt6t.1

This article is protected by copyright. All rights reserved. 


\section{LITERATURE CITED}

Abbadie, L., Gignoux, J., Le Roux, X., \& Lepage, M. (Eds.). (2006). Lamto : structure, functioning and dynamics of a savanna ecosystem. Retrieved from http://www.documentation.ird.fr/hor/fdi:010039255

Abbadie, L., Gignoux, J., Lepage, M., \& Roux, X. L. (2006). Environmental constraints on living organisms. In L. Abbadie, J. Gignoux, X. L. Roux, \& M. Lepage (Eds.), Lamto (pp. 45-61). https://doi.org/10.1007/0-387-33857-8_4

Abella, S. R., \& Fornwalt, P. J. (2015). Ten years of vegetation assembly after a North American mega fire. Global Change Biology, 21(2), 789-802. https://doi.org/10.1111/gcb.12722

Archer, S., Schimel, D. S., \& Holland, E. A. (1995). Mechanisms of shrubland expansion: land use, climate or $\mathrm{CO}_{2}$ ? Climatic Change, 29(1), 91-99. https://doi.org/10.1007/BF01091640

Bond, W. J., Woodward, F. I., \& Midgley, G. F. (2005). The global distribution of ecosystems in a world without fire. New Phytologist, 165(2), 525-537.

Bruzon, V. (1994). Les pratiques du feu en Afrique subhumide, exemples des milieux savanicoles de la Centrafrique et de la Côte d'Ivoire. In C. Blanc-Pamard \& J. Boutrais (Eds.), Dynamique des systèmes agraires: à la croisée des parcours pasteurs, éleveurs, cultivateurs (pp. 147-163). ORSTOM, Paris.

Brys, R., Jacquemyn, H., \& De Blust, G. (2005). Fire increases aboveground biomass, seed production and recruitment success of Molinia caerulea in dry heathland. Acta Oecologica, 28(3), 299-305. https://doi.org/10.1016/j.actao.2005.05.008

Butler, J. L., \& Briske, D. D. (1988). Population structure and tiller demography of the bunchgrass Schizachyrium scoparium in response to herbivory. Oikos, 51(3), 306312. https://doi.org/10.2307/3565311

This article is protected by copyright. All rights reserved. 
Canales, J., Trevisan, M. C., Silva, J. F., \& Caswell, H. (1994). A demographic study of an annual grass (Andropogon brevifolius Schwarz) in burnt and unburnt savanna. Acta Oecologica, 15(3), 261-273.

Case, M. F., \& Staver, A. C. (2017). Fire prevents woody encroachment only at higher-thanhistorical frequencies in a South African savanna. Journal of Applied Ecology, 54(3), 955-962. https://doi.org/10.1111/1365-2664.12805

Caswell, H. (1989). Matrix population models. Sunderland: Sinauer Associates Inc.

César, J. (1992). Étude de la production biologique des savanes de Côte d'Ivoire et de son utilisation par l'homme: biomasse, valeur pastorale et production fourragère (p. 671). Maisons-Alfort (France): IEMVT-Cirad.

Craine, J. M., Froehle, J., Tilman, D. G., Wedin, D. A., \& Chapin, F. S. (2001). The relationships among root and leaf traits of 76 grassland species and relative abundance along fertility and disturbance gradients. Oikos, 93(2), 274-285.

Crowley, G., \& Garnett, S. (1999). Seeds of the annual grasses Schizachyrium spp. as a food resource for tropical granivorous birds. Austral Ecology, 24(3), 208-220. https://doi.org/10.1046/j.1442-9993.1999.00964.x

Dauget, J.-M., \& Menaut, J.-C. (1992). Evolution sur 20 ans d'une parcelle de savane boisée non protégée du feu dans la réserve de Lamto (Côte-d'Ivoire). Candollea, 47(2), 621630.

Fair, J., Lauenroth, W. K., \& Coffin, D. P. (1999). Demography of Bouteloua gracilis in a mixed prairie: analysis of genets and individuals. Journal of Ecology, 87, 233-243.

February, E. C., Higgins, S. I., Bond, W. J., \& Swemmer, L. (2013). Influence of competition and rainfall manipulation on the growth responses of savanna trees and grasses. Ecology, 94(5), 1155-1164. https://doi.org/10.1890/12-0540.1

This article is protected by copyright. All rights reserved. 
Fetcher, N., \& Shaver, G. R. (1982). Growth and tillering patterns within tussocks of Eriophorum vaginatum. Holarctic Ecology, 5(2), 180-186. https://doi.org/10.1111/j.1600-0587.1982.tb01034.x

Garnier, L. K. M., \& Dajoz, I. (2001). The influence of fire on the demography of a dominant grass species of West African savannas, Hyparrhenia diplandra. Journal of Ecology, 89(2), 200-208. https://doi.org/10.1046/j.1365-2745.2001.00532.x

Gautier, L. (1990). Contact forêt-savane en Côte d'Ivoire centrale: évolution du recouvrement ligneux des savanes de la Réserve de Lamto (sud du V-Baoulé). Candollea, 45(2), $627-641$.

Gignoux, J., Dajoz, I., Durand, J., Garnier, L., \& Veuille, M. (2006). Spatial pattern, dynamics, and reproductive biology of the grass community. In L. Abbadie, J. Gignoux, X. Le Roux, \& M. Lepage (Eds.), Lamto (pp. 315-334). https://doi.org/10.1007/978-0-387-33857-6_17

Gignoux, J., Lahoreau, G., Julliard, R., \& Barot, S. (2009). Establishment and early persistence of tree seedlings in an annually burned savanna. Journal of Ecology, 97(3), 484-495. https://doi.org/10.1111/j.1365-2745.2009.01493.x

Gillson, L. (2015). Evidence of a tipping point in a Southern African savanna? Ecological Complexity, 21, 78-86. https://doi.org/10.1016/j.ecocom.2014.12.005

Hartnett, D. C., \& Bazzaz, F. A. (1985). The genet and ramet population dynamics of Solidago canadensis in an abandoned field. The Journal of Ecology, 73(2), 407-413. https://doi.org/10.2307/2260483

Kattge, J., Díaz, S., Lavorel, S., Prentice, I. C., Leadley, P., Bönisch, G., .. Wirth, C. (2011). TRY - a global database of plant traits. Global Change Biology, 17(9), 2905-2935. https://doi.org/10.1111/j.1365-2486.2011.02451.x

This article is protected by copyright. All rights reserved. 
Keeley, J. E., Pausas, J. G., Rundel, P. W., Bond, W. J., \& Bradstock, R. A. (2011). Fire as an evolutionary pressure shaping plant traits. Trends in Plant Science, 16(8), 406-411. https://doi.org/10.1016/j.tplants.2011.04.002

Koffi, K. F., N’Dri, A. B., Lata, J.-C., Konaté, S., Srikanthasamy, T., Konan, M., \& Barot, S. (2019). Effect of fire regime on the grass community of the humid savanna of Lamto, Ivory Coast. Journal of Tropical Ecology, 35(1), 1-7. https://doi.org/10.1017/S0266467418000391

Laris, P., Koné, M., Dadashi, S., \& Dembele, F. (2017). The early/late fire dichotomy: time for a reassessment of Aubréville's savanna fire experiments. Progress in Physical Geography: Earth and Environment, 41(1), 68-94. https://doi.org/10.1177/0309133316665570

Lata, J. C. (1999). Interactions entre processus mocrobiens, cycle des nutriments et et fonctionnement du couvert herbacé: cas de la nitrification dans les sols d'une savane humide de Côte d'Ivoire sous couvert à Hyparrhenia diplandra (Thèse de doctorat). Université Pierre et Marie Curie, Paris, France.

Louppe, D., Oattara, N., \& Coulibaly, A. (1995). The effects of bush fires on vegetation: the Aubréville fire plots after 60 years. The Commonwealth Forestry Review, 74(4), 288292.

Loydi, A., Eckstein, R. L., Otte, A., Donath, T. W., \& Gómez-Aparicio, L. (2013). Effects of litter on seedling establishment in natural and semi-natural grasslands: a metaanalysis. Journal of Ecology, 101(2), 454-464. https://doi.org/10.1111/13652745.12033

Menaut, J.-C., \& Abbadie, L. (2006). Vegetation. In L. Abbadie, J. Gignoux, X. L. Roux, \& M. Lepage (Eds.), Lamto (pp. 63-74). https://doi.org/10.1007/0-387-33857-8_5

This article is protected by copyright. All rights reserved. 
Milton, S. J., \& Dean, W. R. J. (2000). Disturbance, drought and dynamics of desert dune grassland, South Africa. Plant Ecology, 150(1-2), 37-51.

Mishra, N. B., \& Young, K. R. (2014). Savannas and grasslands. In Taylor \& Francis (Eds.), Encyclopedia of natural resources: land (pp. 403-412). https://doi.org/10.1081/EENRL

Moleele, N. M., Ringrose, S., Matheson, W., \& Vanderpost, C. (2002). More woody plants? the status of bush encroachment in Botswana's grazing areas. Journal of Environmental Management, 64(1), 3-11. https://doi.org/10.1006/jema.2001.0486

Monnier, Y. (1968). Les effets des feux de brousse sur une savane préforestière de Côted'Ivoire. Abidjan, Côte d'Ivoire: Ministère de l'éducation nationale de la République de Côte-d'Ivoire.

Moore, N. A., Camac, J. S., \& Morgan, J. W. (2019). Effects of drought and fire on resprouting capacity of 52 temperate Australian perennial native grasses. New Phytologist, 221(3), 1424-1433. https://doi.org/10.1111/nph.15480

N'Dri, A. B., Kone, A. W., Loukou, S. K. K., Barot, S., \& Gignoux, J. (2018). Carbon and nutrient losses through biomass burning, and links with soil fertility and yam (Dioscorea alata) production. Experimental Agriculture, 1-14. https://doi.org/10.1017/S0014479718000327

N’Dri, A. B., Soro, T. D., Gignoux, J., Dosso, K., Koné, M., N’Dri, J. K., ... Barot, S. (2018). Season affects fire behavior in annually burned humid savanna of West Africa. Fire Ecology, 14(2), 1-11. https://doi.org/10.1186/s42408-018-0005-9

O'Connor, T. G. (1994). Composition and population responses of an African savanna grassland to rainfall and grazing. The Journal of Applied Ecology, 31(1), 155-171. https://doi.org/10.2307/2404608

This article is protected by copyright. All rights reserved. 
Oliva, G., Collantes, M., \& Humano, G. (2005). Demography of grazed tussock grass populations in Patagonia. Rangeland Ecology \& Management, 58(5), 466-473. https://doi.org/10.2111/1551-5028(2005)58[466:DOGTGP]2.0.CO;2

Orr, D. M. (1980). Effects of sheep grazing Astrebla grassland in Central Western Queensland. 1. Effects of grazing pressure and livestock distribution. Australian Journal of Agricultural Research, 31(4), 797-806. https://doi.org/10.1071/ar9800797

Pelaez, D. V., Boo, R. M., Mayor, M. D., \& Elia, O. R. (2001). Effect of fire on perennial grasses in central semiarid Argentina. Journal of Range Management, 54(5), 617621. https://doi.org/10.2307/4003593

Rees, M., \& Crawley, M. J. (1989). Growth, reproduction and population dynamics. Functional Ecology, 3(6), 645-653. https://doi.org/10.2307/2389496

Ritchie, M. E., Tilman, D., \& Knops, J. M. H. (1998). Herbivore effects on plant and nitrogen dynamics in oak savanna. Ecology, 79(1), 165. https://doi.org/10.2307/176872

Sarmiento, G. (1992). Adaptive strategies of perennial grasses in South American savannas. Journal of Vegetation Science, 3(3), 325-336. https://doi.org/10.2307/3235757

Silva, J. F., \& Ataroff, M. (1985). Phenology, seed crop and germination of coexisting grass species from a tropical savanna in Wester Venezuela. Acta Oecologica, 6 (20)(1), 4151.

Silva, J. F., \& Castro, F. (1989). Fire, growth and survivorship in a neotropical savanna grass Andropogon semiberbis in Venezuela. Journal of Tropical Ecology, 5(4), 387-400.

Silva, J. F., Raventos, J., \& Caswell, H. (1990). Fire and fire exclusion effects on the growth and survival of two savanna grasses. Acta Oecologica, 11(6), 783-800.

Smit, I. P. J., Asner, G. P., Govender, N., Vaughn, N. R., \& van Wilgen, B. W. (2016). An examination of the potential efficacy of high-intensity fires for reversing woody

This article is protected by copyright. All rights reserved. 
encroachment in savannas. Journal of Applied Ecology, 53(5), 1623-1633. https://doi.org/10.1111/1365-2664.12738

Soreng, R. J., Peterson, P. M., Romaschenko, K., Davidse, G., Zuloaga, F. O., Judziewicz, E. J., ... Morrone, O. (2015). A worldwide phylogenetic classification of the Poaceae (Gramineae): phylogenetic classification of the grasses. Journal of Systematics and Evolution, 53(2), 117-137. https://doi.org/10.1111/jse.12150

Sosef, M. S. M. (2016). Taxonomic novelties in Central African grasses (Poaceae), Paniceae 1. Plant Ecology and Evolution, 149(3), 356-365. https://doi.org/10.5091/plecevo.2016.1221

Stevens, N., Lehmann, C. E. R., Murphy, B. P., \& Durigan, G. (2017). Savanna woody encroachment is widespread across three continents. Global Change Biology, 23(1), 235-244. https://doi.org/10.1111/gcb.13409

Violle, C., Navas, M.-L., Vile, D., Kazakou, E., Fortunel, C., Hummel, I., \& Garnier, E. (2007). Let the concept of trait be functional! Oikos, 116(5), 882-892. https://doi.org/10.1111/j.0030-1299.2007.15559.x

Watkinson, A. R., \& White, J. (1986). Some life-history consequences of modular construction in plants. Philosophical Transactions of the Royal Society B: Biological Sciences, 313(1159), 31-51. https://doi.org/10.1098/rstb.1986.0024

Weaver, S. E., \& Cavers, P. B. (1980). Reproductive effort of two perennial weed species in different habitats. The Journal of Applied Ecology, 17(2), 505-513. https://doi.org/10.2307/2402345

Williams, R. J., Müller, W. J., Wahren, C.-H., Setterfield, S. A., \& Cusack, J. (2003). Vegetation. In A. N. Andersen, G. D. Cook, \& R. J. Williams (Eds.), Fire in Tropical Savannas (pp. 79-106). https://doi.org/10.1007/0-387-21515-8_6

This article is protected by copyright. All rights reserved. 
Yuan, J., Liang, D., \& Zhang, S. (2016). Litter and its interaction with standing vegetation affect seedling recruitment in Tibetan alpine grasslands. Plant Ecology \& Diversity, 9(1), 89-95. https://doi.org/10.1080/17550874.2015.1073400

Zimmermann, J., Higgins, S. I., Grimm, V., Hoffmann, J., \& Linstädter, A. (2010). Grass mortality in semi-arid savanna: the role of fire, competition and self-shading. Perspectives in Plant Ecology, Evolution and Systematics, 12(1), 1-8. https://doi.org/10.1016/j.ppees.2009.09.003

This article is protected by copyright. All rights reserved. 
Table 1: Abundance and proportion of perennial grasses on all plots the first and second years of study (overall tussocks).

Species Abundance Proportion the Abundance the Proportion the the first year first year (\%) second year second year (\%)

\begin{tabular}{lcccc}
\hline Andropogon ascinodis & 105 & 2 & 116 & 2 \\
Andropogon canaliculatus & 1588 & 31 & 1842 & 34 \\
Andropogon schirensis & 494 & 10 & 494 & 9 \\
Brachiaria brachylopha & 81 & 2 & 127 & 2 \\
Hyparrhenia diplandra & 1351 & 26 & 1326 & 25 \\
Hyparrhenia smithiana & 188 & 4 & 176 & 3 \\
Loudetia simplex & 777 & 15 & 823 & 15 \\
Sorghastrum bipennatum & 294 & 6 & 282 & 5 \\
Schizachyrium platyphyllum & 238 & 5 & 169 & 3 \\
\hline
\end{tabular}

This article is protected by copyright. All rights reserved. 
Table 2: Table showing (1) the $\chi^{2}$ values of binary logistic regressions analyzing the effect of fire treatment, grass species, tussock circumference and two and three way interactions the interactions on tussock probability to die, to become fragmented, to grow and to retrogress using the glmer procedure, (2) the F values for linear regression analyzing the effect of fire treatment, grass species, tussock circumference and two and three way interactions on the number of seed produced by grasses and the production of new tussocks using the $1 \mathrm{~m}$ procedure. Only significant effects are displayed: ***, $P<0.001$; **, $P<0.01$; ${ }^{*}, P<0.05$. df: degrees of freedom.

\begin{tabular}{|c|c|c|c|c|c|}
\hline $\begin{array}{l}\text { Explained } \\
\text { variables }\end{array}$ & Explanatory variables & $\begin{array}{c}\text { Procedure } \\
\text { used }\end{array}$ & $\begin{array}{c}\text { Value of the } \\
\text { statistic }\end{array}$ & $d f$ & $p$-value \\
\hline \multirow{6}{*}{$\begin{array}{l}\text { Tussock } \\
\text { mortality }\end{array}$} & Circumference & \multirow{6}{*}{ glmer } & $\chi^{2}=212.43$ & 1 & $* * *$ \\
\hline & Fire treatment & & $\chi^{2}=435.67$ & 3 & $* * *$ \\
\hline & Species & & $\chi^{2}=128.55$ & 8 & $* * *$ \\
\hline & Circumference $\times$ Fire treatment & & $\chi^{2}=11.13$ & 3 & $* *$ \\
\hline & Circumference $\times$ Species & & $\chi^{2}=33.63$ & 8 & $* * *$ \\
\hline & Fire treatment $\times$ Species & & $\chi^{2}=104.1$ & 23 & $* * *$ \\
\hline \multirow{3}{*}{$\begin{array}{l}\text { Tussock } \\
\text { fragmentation }\end{array}$} & Circumference & \multirow{3}{*}{ glmer } & $\chi^{2}=149.95$ & 1 & $* * *$ \\
\hline & Fire treatment & & $\chi^{2}=31.79$ & 3 & $* * *$ \\
\hline & Species & & $\chi^{2}=33.92$ & 8 & $* * *$ \\
\hline \multirow{6}{*}{$\begin{array}{l}\text { Tussock } \\
\text { growth }\end{array}$} & Circumference & \multirow{6}{*}{ glmer } & $\chi^{2}=98.81$ & 1 & $* * *$ \\
\hline & Fire treatment & & $\chi^{2}=167.52$ & 3 & $* * *$ \\
\hline & Species & & $\chi^{2}=88.74$ & 8 & $* * *$ \\
\hline & Circumference $\times$ Fire treatment & & $\chi^{2}=59.1$ & 3 & $* * *$ \\
\hline & Circumference $\times$ Species & & $\chi^{2}=18.85$ & 8 & * \\
\hline & Fire treatment $\times$ Species & & $\chi^{2}=62.13$ & 23 & $* * *$ \\
\hline \multirow{6}{*}{$\begin{array}{l}\text { Tussock } \\
\text { retrogression }\end{array}$} & Circumference & \multirow{6}{*}{ glmer } & $\chi^{2}=529.96$ & 1 & $* * *$ \\
\hline & Fire treatment & & $\chi^{2}=168.92$ & 3 & $* * *$ \\
\hline & Species & & $\chi^{2}=28.91$ & 8 & $* * *$ \\
\hline & Circumference $\times$ Fire treatment & & $\chi^{2}=36.05$ & 3 & $* * *$ \\
\hline & Circumference $\times$ Species & & $\chi^{2}=28.69$ & 8 & $* * *$ \\
\hline & Fire treatment $\times$ Species & & $\chi^{2}=54.09$ & 23 & $* * *$ \\
\hline \multirow{3}{*}{$\begin{array}{c}\text { Seed } \\
\text { production }\end{array}$} & Circumference & \multirow{3}{*}{$\operatorname{lm}$} & $\mathrm{F}=40.24$ & 1 & $* * *$ \\
\hline & Fire treatment & & $\mathrm{F}=10.34$ & 3 & $* * *$ \\
\hline & Species & & $F=14.65$ & 8 & $* * *$ \\
\hline
\end{tabular}

This article is protected by copyright. All rights reserved. 
Fire treatment $\times$ Species

Fire treatment $\times$ Circumference

Species $\times$ Circumference

Fire treatment $\times$ Species $\times$

Circumference
$\mathrm{F}=6.36 \quad 24 \quad * * *$

$\mathrm{F}=3.1 \quad 3 \quad *$

$\mathrm{F}=7.1 \quad 8 \quad * * *$

$\mathrm{F}=2,97 \quad 23 \quad * * *$

Production of new tussocks

Species

$\operatorname{lm} \quad \mathrm{F}=4.38$

$8 \quad * * *$

Figure 1: Tussock mortality as a function of fire treatment, grass species and tussock circumference. Boxplots ( $\mathrm{a}$ and $\mathrm{b}$ ): horizontal bold lines of boxes indicate the median, the lower and upper bounds of boxes represent the 25th and 75th percentiles, respectively. The vertical doted bars include all values except outliers (circles). Significant differences between fire treatments and grass species are indicated by different letters (Tukey HSD test). EF, Early fire; LF, Late fire; MF, Mid-season fire; NF, No fire; AA, Andropogon ascinodis; AC, Andropogon canaliculatus; AS, Andropogon schirensis; BB, Brachiaria brachylopha; HD, Hyparrhenia diplandra; HS, Hyparrhenia smithiana; LS, Loudetia simplex; SB, Sorghastrum bipennatum; SP, Schizachyrium platiphylum. Logistic regressions (c and d): the colored lines indicate the probability of mortality as a function of tussock circumference as predicted by logistic regression. Each color represents a fire treatment (c) or a species (d).

Figure 2: Fragmentation of tussocks as a function of fire treatment, grass species and tussock circumference. Boxplots (a and b). Logistic regressions ( $c$ and d): the colored lines indicate the probability of tussock fragmentation as a function of their circumference. Each color line represents a fire treatment (c) or a species (d). Otherwise same legend as for Fig. 1.

This article is protected by copyright. All rights reserved. 
Figure 3: Tussocks growth as a function of fire treatment, grass species and tussock circumference. Boxplots (a and b). Logistic regressions (c and d): the colored lines indicate the probability of tussock growth as a function of circumference. Each color line represents a fire treatment (c) or a species (d). Otherwise same legend as for Fig. 1.

Figure 4: Tussock retrogression as a function of fire treatment, grass species and tussock circumference. Boxplots ( $\mathrm{a}$ and $\mathrm{b}$ ). Each color line represents a fire treatment (c) or a species (d). Otherwise same legend as for Fig. 1.

Figure 5: Seed production by tussock as a function of fire treatment (a), grass species (b) and tussock circumference (c and d). (c) and (d) represent the regression of the number of seed on the tussock circumference. Each colored line represents a fire treatment (c) or a species (d). Otherwise same legend as for Fig. 1.

Figure 6: Fecundity measured as the number of new tussocks per tussock of the same species as a function of species. Otherwise same legend as for Fig. 1.

This article is protected by copyright. All rights reserved. 

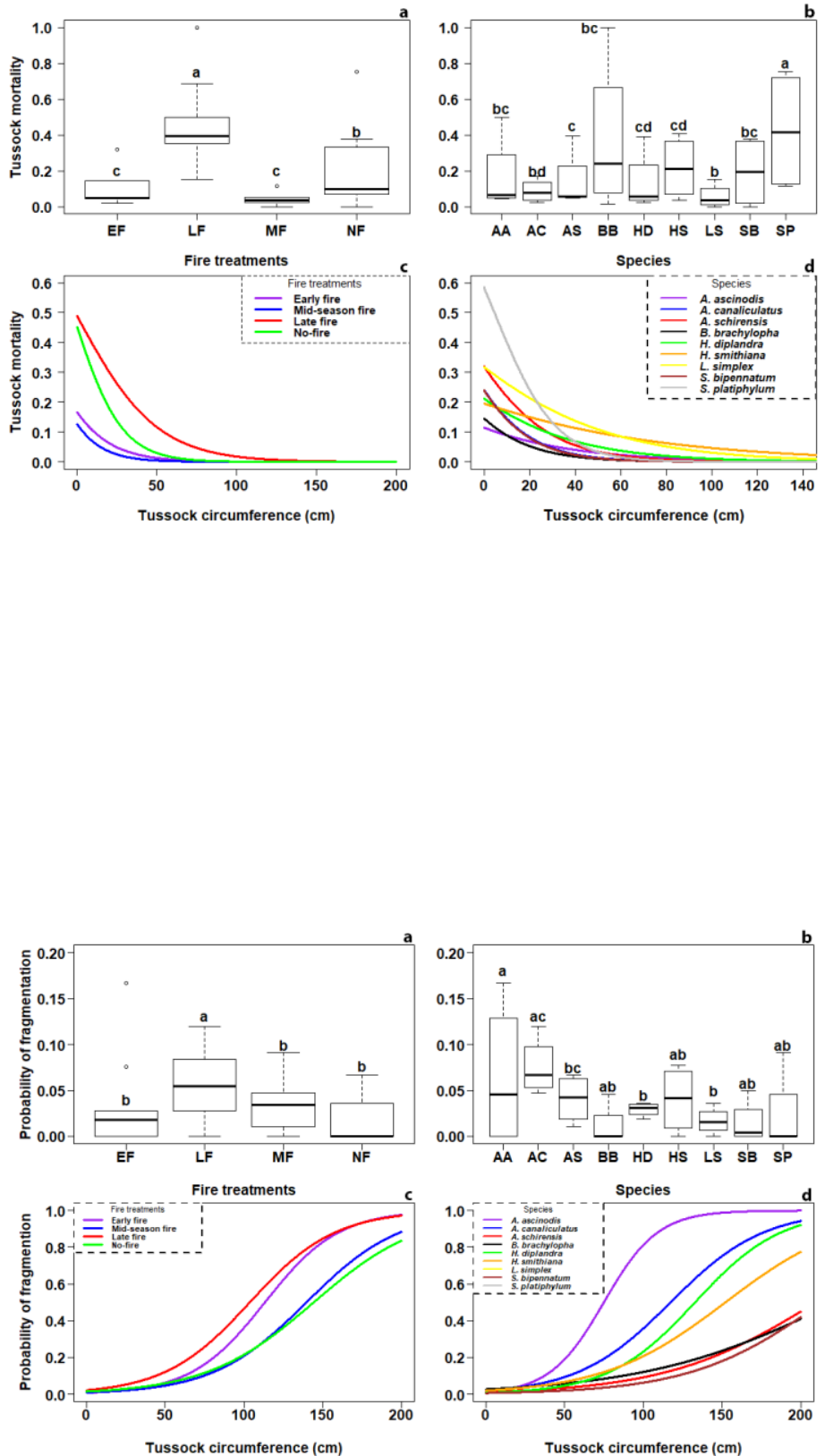

This article is protected by copyright. All rights reserved. 

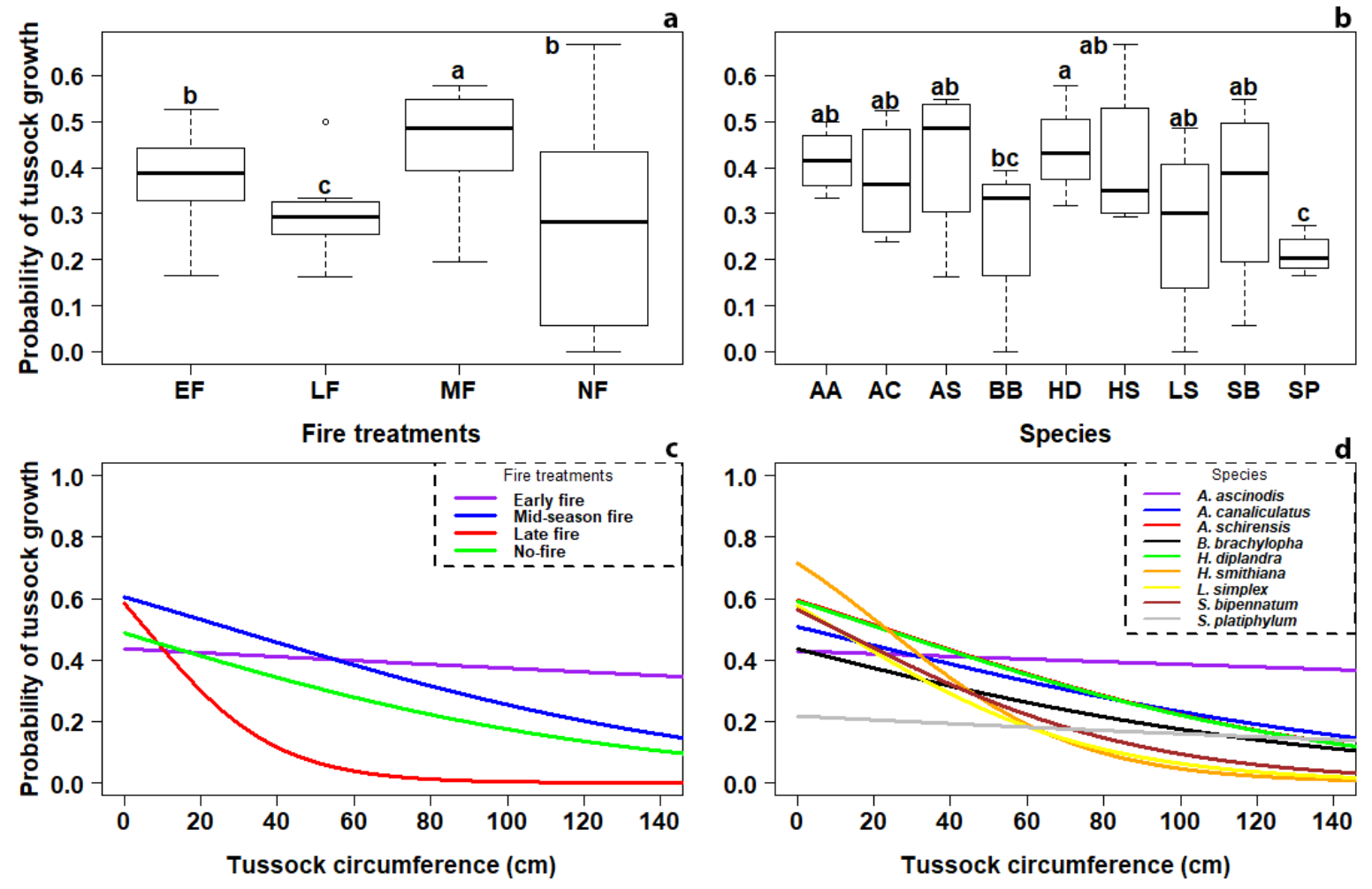

This article is protected by copyright. All rights reserved. 

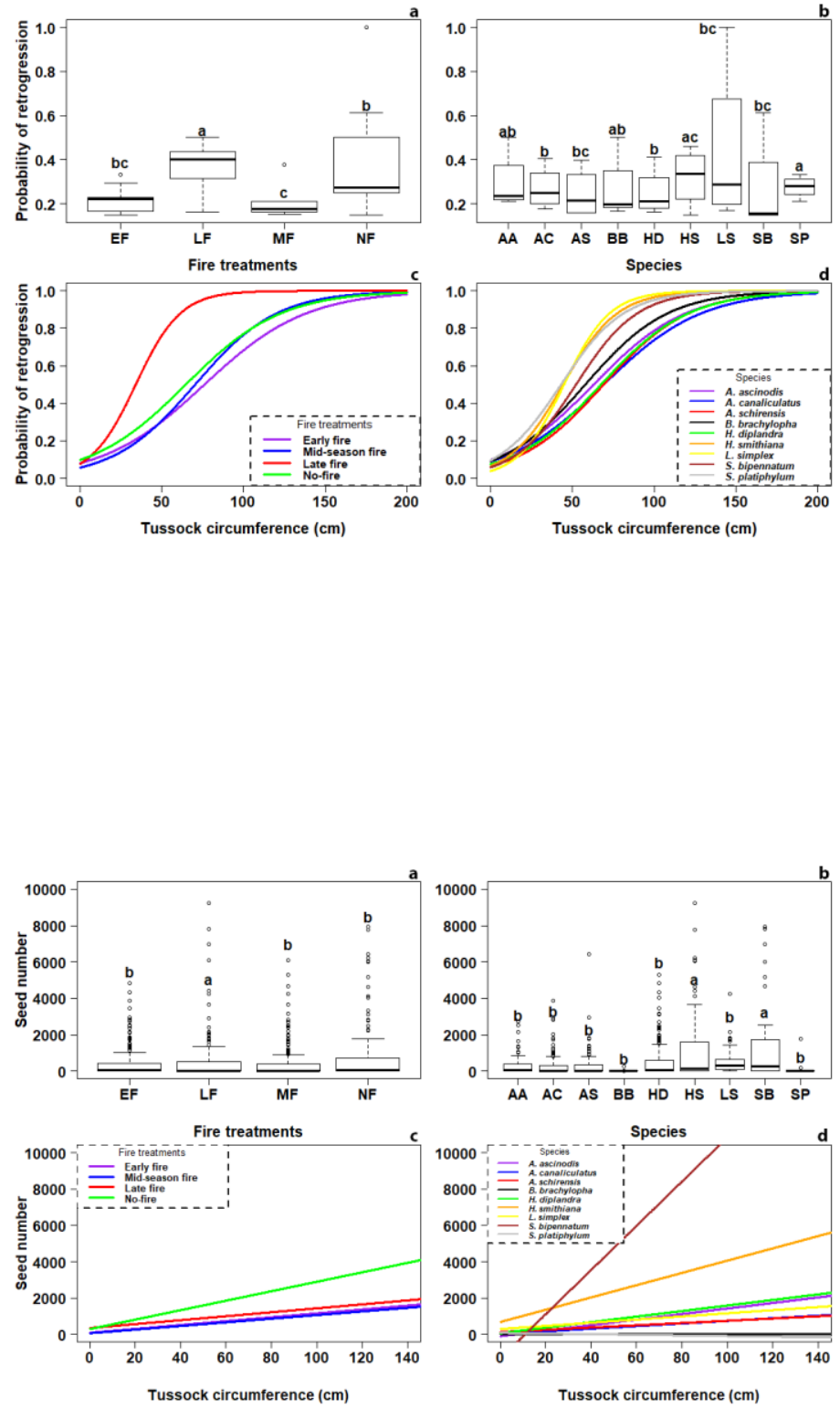

This article is protected by copyright. All rights reserved. 


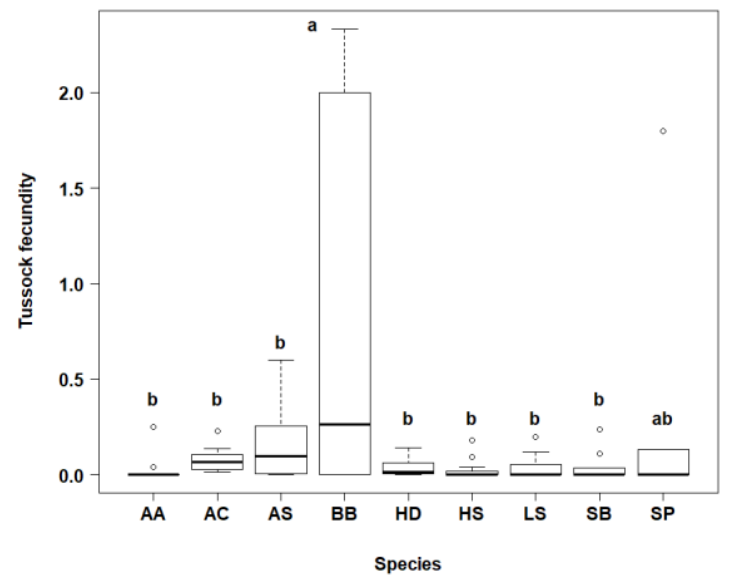

This article is protected by copyright. All rights reserved. 